\title{
Harvest method does not affect survival and condition during gonad enhancement of an overabundant sea urchin
}

\author{
F. Warren-Myers ${ }^{1,2, *}$, S. E. Swearer ${ }^{2}$, D. S. Francis ${ }^{3}$, G. M. Turchini ${ }^{3}$, T. Dempster ${ }^{1}$ \\ ${ }^{1}$ Sustainable Aquaculture Laboratory - Temperate and Tropical (SALTT), School of Biosciences, University of Melbourne, \\ Victoria 3010, Australia \\ ${ }^{2}$ National Centre for Coasts and Climate (NCCC) and School of BioSciences, University of Melbourne, Victoria 3010, \\ Australia \\ ${ }^{3}$ School of Life and Environmental Sciences, Faculty of Science, Engineering and Built Environment, Deakin University, \\ Geelong, Victoria 3220, Australia
}

\begin{abstract}
Interest in sea urchin roe enhancement aquaculture is growing due to an increased global demand for high-quality roe that is suitable for export to international markets. Yet, finetuning of efficient collection methods and improved growing techniques are still key bottlenecks to industry success. Urchins suitable for roe enhancement are generally collected from rocky barrens where they occur in high densities. Few studies have investigated the efficiency of methods used to collect urchins from barrens or the associated short- and long-term handling effects due to collection methods. Here, we tested 2 methods to collect the purple sea urchin Heliocidaris erythrogramma, a species that is highly abundant in barrens in temperate waters and which is a viable candidate for roe enhancement aquaculture. We assessed short- and long-term survival, external urchin condition and final gonad indices after $12 \mathrm{wk}$ of roe enhancement. Divers using a 3-pronged hook and catch bag collected urchins 1.9 times faster (392 urchins $\mathrm{h}^{-1}$ ) than careful hand collection (207 urchins $\mathrm{h}^{-1}$ ). Collection method did not significantly influence mortality rate, external health or gonad indices after $12 \mathrm{wk}$ of roe enhancement. Our results show that $H$. erythrogramma in barrens is robust to rapid mechanical collection by divers, which increases its suitability as a candidate capture-based aquaculture species.
\end{abstract}

KEY WORDS: Urchin barrens · Gonad index · Collection rate $\cdot$ Urchin condition · Heliocidaris erythrogramma

\section{INTRODUCTION}

The transformation of macro-algal dominated rocky reefs to urchin barrens due to grazing pressure from high densities of sea urchins is a worldwide phenomenon (Scheibling et al. 1999, Shears \& Babcock 2002, Steneck et al. 2002, Ling et al. 2015). The shift to urchin barrens results in dramatic decreases in algal cover, taxonomic diversity and primary production (Chapman 1981, Ling 2008, Johnson et al. 2015). While removing urchins from barrens can re-establish algal cover (Fletcher 1987, Andrew \&

*Corresponding author: fletcher.warren@unimelb.edu.au
Underwood 1993, Claisse et al. 2013, Tracey et al. 2014, 2015, Kriegisch et al. 2016), this practice is too costly for broad-scale application (e.g. Tracey et al. 2014). Creating an economic driver that results in the removal of urchins from barrens, by making each urchin valuable through roe enhancement aquaculture, could be a cost-effective alternative to reduce urchin abundances (Pert et al. 2018) and enable the re-establishment of macro-algal dominated reefs.

Sea urchin roe is a highly-valued export food commodity, and the demand for high-quality roe has driven development of sea urchin aquaculture world-

(C) The authors 2019. Open Access under Creative Commons by Attribution Licence. Use, distribution and reproduction are unrestricted. Authors and original publication must be credited. 
wide (e.g. Norway, New Zealand, Israel, Chile, USA, Japan and China; Lawrence 2001). Roe enhancement involves capturing urchins from the wild and feeding them with a high-quality diet in an aquaculture setting to increase the quantity and quality of the roe. Successful roe enhancement is now possible for many species of urchins (e.g. Robinson et al. 2002, Shpigel et al. 2005, Böttger et al. 2006, Woods et al. 2008, Suckling et al. 2011, Pert et al. 2018), yet whether roe enhancement is feasible on an industrial scale remains questionable due to both production and market challenges (e.g. James et al. 2017).

In southern Australia, the purple sea urchin Heliocidaris erythrogramma supports a small commercial fishery for local markets. However, the majority of wild $H$. erythrogramma occur in high densities within barrens (Johnson et al. 2015, Kriegisch et al. 2016), which are unsuitable for harvest due to low or inconsistent gonad content (Pert et al. 2018). Collecting $H$. erythrogramma from barrens for roe enhancement could use this natural resource, create a new export industry and provide ecosystem benefits by reducing urchin densities and allowing barrens to return to natural macroalgal reefs (Kriegisch et al. 2016). Roe enhancement of $H$. erythrogramma in land-based facilities has produced urchins with marketable gonad indices (GIs) (e.g. Musgrove 2005, Senaratna et al. 2005, Pert et al. 2018), yet several constraints remain to industry development.

The success of capture-based aquaculture industries relies heavily on animals brought into aquaculture settings from the wild being in good health, giving them the greatest chance of successfully transitioning to a captive environment (e.g. Midling et al. 2012, Olsen et al. 2013). Capture techniques are a critical step in this process. For sea urchins, collections should be as rapid as possible to reduce the unit cost of collection, and they should be held in optimal conditions during transport so that there are limited short- or longer-term effects on survival rates and high GIs during roe enhancement.

Handling and air exposure during collection of urchins for roe enhancement influence mortality rates during the first few weeks post collection and the final GI at the end of the roe enhancement period (Dale et al. 2005). Furthermore, air exposure during harvest reduces the shelf life of extracted roe due to increased $\mathrm{CO}_{2}$ and a drop in $\mathrm{pH}$ in the gut (Verachia et al. 2012). Achieving acceptable GI levels at harvest is also influenced by urchin external condition at collection and during enhancement, as injured urchins with scarring or spine loss often have lower
GIs compared to those without injury (Dale et al. 2005). Hence, any collection method that increases handling, duration of air exposure, the amount of test scarring or spine loss may result in higher mortality or a lower-value product at harvest.

Collection methods for $H$. erythrogramma intended for roe enhancement trials range from scuba divers gently hand picking urchins and transporting them in cool boxes containing oxygenated seawater (Pert et al. 2018), to the use of hook and catch bags and transporting in plastic tubs covered with wet hessian (burlap) bags (e.g. James 2006, James et al. 2017). The speed of collection and possible after-effects on urchins due to these methods remain unknown. Here, we compared 2 collection methods for $H$. erythrogramma: (1) gentle hand collection method intended to minimise handling stress for urchins; and (2) hook and catch bag method, which mimics the current commercial diver rapid collection technique for urchins that go directly to local markets. Here, we focussed on the physical handling effects of collection and minimised any effects of air exposure for both collection methods after diver collection by holding urchins in seawater aerated with $\mathrm{O}_{2}$ whenever in transit. Determining how efficiently wild urchins can be collected from rocky barrens, while still ensuring high survival and high final GI levels after roe enhancement, is an important factor in ensuring the development of a financially feasible roe enhancement industry.

\section{MATERIALS AND METHODS}

\subsection{Hand vs. hook}

Two collection methods were used to test collection efficiency and handling effects on survival and roe production of Heliocidaris erythrogramma. The first collection method ('gentle hand and container', GHC) involved 2 divers carefully handpicking urchins and gently placing them into 41 individually partitioned plastic containers for transport to the surface. The second method ('hook and catch bag', HCB) involved the same 2 divers rapidly collecting urchins using a hand-sized 3-pronged hook and spring-loaded, mesh catch bags.

\subsection{Collection}

On 5 June 2017, each collection method was tested 3 times on a rocky urchin barren in the north- 
ern part of Port Philip Bay $\left(37.87^{\circ} \mathrm{S}, 144.85^{\circ} \mathrm{E}\right)$, Australia, approximately $0.5 \mathrm{~km}$ offshore. Sea surface temperature at the time of collection was $\sim 15^{\circ} \mathrm{C}$, and the depth of collection was $2-4 \mathrm{~m}$. For the GHC method, 2 divers collected 42 urchins into 6 grilled plastic containers $(7$ urchins per $4 \mathrm{l}$ container). For each replicate, 6 full containers were returned to the boat and packed 2 abreast, 3 deep, into a 331 plastic cool box (internal dimensions: length 385 $\mathrm{mm}$, width $245 \mathrm{~mm}$, height $350 \mathrm{~mm}$ ) containing seawater. For the HCB method, 2 divers collected 42 urchins into catch bags ( 21 ind. bag $^{-1}$ diver $^{-1}$ ). Full catch bags were returned to the boat and urchins were emptied directly into $331 \mathrm{cool}$ boxes containing seawater (1 cool box per replicate). Seawater was replenished in each cool box approximately every 10 min using a 101 bucket during the diver collection phase. Total diver submergence time taken for each replicate collection $(3 \times$ GHC and $3 \times$ $\mathrm{HCB}$ ) was used to estimate urchin collection rates. After collection was complete, all cool boxes were aerated with pure $\mathrm{O}_{2}$ via an airline and air stone $\left(0.5-1 \mathrm{l} \mathrm{O}_{2} \mathrm{~min}^{-1} \mathrm{box}^{-1}\right)$ for transport. Urchins were transported $0.5 \mathrm{~km}$ by boat to land and then $100 \mathrm{~km}$ by vehicle to the land-based aquaculture facility in Queenscliff, Victoria. On arrival at the facility, urchins were placed into 181 tanks at a density of 10-12 ind. tank $^{-1}$ (i.e. 4 randomly selected tanks for each cool box). Total transport time from when collection first started and the last urchins were placed in tanks at the onshore aquaculture facility was $<3 \mathrm{~h}$. Each tank received ambient seawater $\left(14.2^{\circ} \mathrm{C}\right)$ at a continuous flow-through rate of 0.5-1 $1 \mathrm{~min}^{-1}$. Tanks were housed indoors and experienced a 12:12 h light:dark photoperiod under incandescent lighting. Urchins were then monitored for $2 \mathrm{wk}$ to assess any direct effects on condition and survival due to collection method. During these $2 \mathrm{wk}$, urchins were fed a high-protein artificial diet (Pert et al. 2018) ad libitum $\left(6 \mathrm{~g} \mathrm{tank}^{-1}\right)$ once every 2 to $3 \mathrm{~d}$.

\subsection{Gonad enhancement}

After the initial $2 \mathrm{wk}, 3$ of the 4 tanks of urchins from each cool box ( 3 tanks $\times 10$ urchins $\times 6$ cool boxes $=180$ urchins in total) were fed $6 \mathrm{~g}$ of the high-protein artificial diet used by Pert et al. (2018) 3 times a week for a further $10 \mathrm{wk}$ to assess long-term effects on total mortality, condition and roe enhancement. Faecal matter and any remaining feed were siphoned from the tanks just prior to the next feeding. The high-protein diet used contained approximately $40 \mathrm{~g} \mathrm{~kg}^{-1}$ moisture, $453.5 \mathrm{~g}$ $\mathrm{kg}^{-1}$ protein, $59.2 \mathrm{~g} \mathrm{~kg}^{-1}$ lipid, $59.8 \mathrm{~g} \mathrm{~kg}^{-1}$ ash, $387.5 \mathrm{~g}$ $\mathrm{kg}^{-1}$ nitrogen-free extract and $19.7 \mathrm{MJ} \mathrm{kg}^{-1}$ energy (see Pert et al. 2018 for full details). At $12 \mathrm{wk}$ post collection, gonads were dissected and a GI was estimated using the formula:

$$
\begin{gathered}
\% \mathrm{GI}=\text { urchin gonad wet weight } / \text { urchin total } \\
\text { wet weight } \times 100
\end{gathered}
$$

Indication of the quality of gonads was based on colour, texture and firmness following the gonad grading guidelines (A, B, C and D grade) of Pert et al. (2018). A, B and C grades were considered to be of premium, high or mediocre commercial quality, respectively, and D grade was considered unacceptable commercial quality. Urchin external condition was categorised into 3 classes: healthy, average or poor (Fig. 1). Urchins with no spine loss or scarring were classed as heathy; urchins with some spine loss $(<25 \%)$ and no scarring were classed as average; and urchins with major spine loss (>25\%) and/or scarring were classed as poor. Ambient seawater temperature in the onshore facility dropped from 14.4 to $12.3^{\circ} \mathrm{C}$ during the $12 \mathrm{wk}$ enhancement period.

\subsection{Statistical analysis}

Mean collection rate and mean GI for each collection ( $\mathrm{n}=3$ collections each for GHC and HCB) after $12 \mathrm{wk}$ were analysed using paired sample $t$-tests. Box plots and QQ-plots were used to check that data were normally distributed and homo-

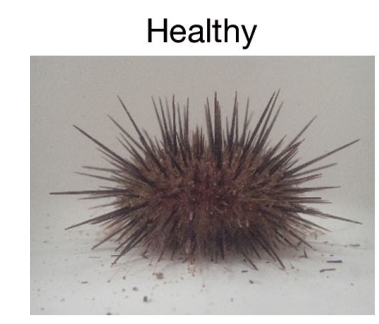

$\mathrm{HCB}=92 \pm 6.4 \%$

$\mathrm{GHC}=87 \pm 1.0 \%$

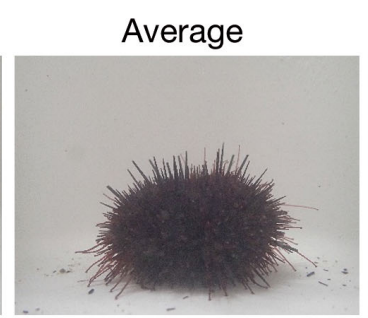

$\mathrm{HCB}=8 \pm 6.4 \%$

$\mathrm{GHC}=11 \pm 1.1 \%$

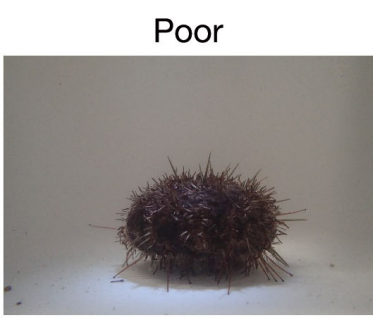

$\mathrm{HCB}=0 \%$

$\mathrm{GHC}=1 \pm 1.0 \%$

Fig. 1. Urchin external condition. Proportion of urchins classified as (a) healthy (no spine loss), (b) average ( $<25 \%$ spine loss) or (c) poor ( $>25 \%$ spine loss or with scarring) after $12 \mathrm{wk}$ of roe enhancement (mean $\pm \mathrm{SE}$ ). Collection methods were HCB: hook and catch bag; GHC: gentle hand and container 
scedastic. Urchin external condition (healthy and average) and distribution of roe grade (A, B, C and D) after 12 wk were analysed using a Pearson chisquared test.

\section{RESULTS}

\subsection{Collection times}

HCB collection was 1.9 times faster than GHC collection ( $t=41, \mathrm{df}=2, \mathrm{p}=0.001)$. The mean \pm SE time for 2 divers to collect 42 urchins using the HCB method was $3 \min 13 \mathrm{~s} \pm 23 \mathrm{~s}\left(392\right.$ urchins $\mathrm{h}^{-1}$ diver $^{-1}$ ), and for the GHC method it was $6 \min 6 \mathrm{~s} \pm$ 26 s (207 urchins $\mathrm{h}^{-1}$ diver $\left.^{-1}\right)$.

\subsection{Mortality and external condition 2 wk post collection}

Total mortality was $0 \%$ for the GHC collection method and $1.6 \%$ for the HCB method 2 wk post collection. Of the 2 urchins that did die in the $\mathrm{HCB}$ collection method, 1 urchin died on Day 6 and the other on Day 12. A hole was observed in the test approximately the size of a hook prong in the urchin that died on Day 12 (Fig. 2). At the end of $2 \mathrm{wk}$, all remaining urchins appeared to be in excellent health with no obvious spine loss, test scarring or signs of necrosis.

\subsection{Mortality and external condition after $12 \mathrm{wk}$ of roe enhancement}

One further urchin in the GHC treatment dropped spines and died in Week 6. At $12 \mathrm{wk}$ post collection, total mortality was $1.6 \%$ for HCB and $0.8 \%$ for GHC. Mean \pm SE spine loss was $8 \pm 6.4 \%$ for $\mathrm{HCB}$ and $11 \pm$ $1.1 \%$ for GHC, with an additional $1 \pm 1.0 \%$ of GHC urchins in poor condition (Fig. 1). There was no difference between collection methods in either the number of healthy $\left(\chi^{2}=0.65, \mathrm{df}=2, \mathrm{p}>0.05\right)$ or average condition $\left(\chi^{2}=5.44, \mathrm{df}=2, \mathrm{p}>0.05\right)$ urchins.

\subsection{GI and gonad quality}

Initial GI taken from a sample of 20 wild urchins on the collection date was low (mean $\pm \mathrm{SE}=2.1 \pm 0.2 \%$ ). After $12 \mathrm{wk}$ of roe enhancement, both HCB and GHC collection methods showed a 6-fold increase in GI

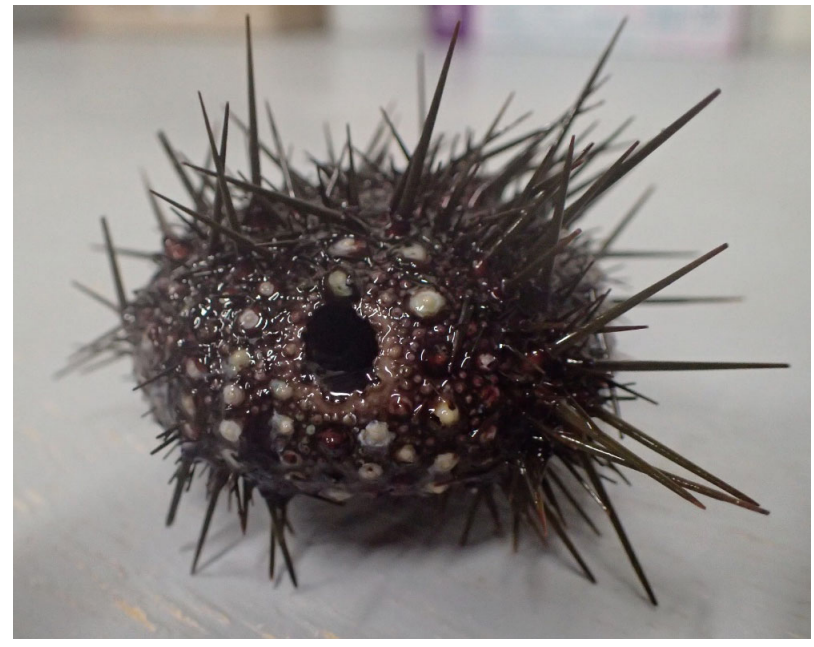

Fig. 2. Urchin test damaged during collection using the hook and catch bag collection method

( $1 \%$ increase in GI per week), but there was no difference in final GI $(t=0.89, \mathrm{df}=2, \mathrm{p}=0.47$; $\mathrm{HCB}=$ $13.5 \pm 0.3 \%$, GHC $12.8 \pm 0.6 \%$ ), or the distribution of roe grades $\left(\mathrm{A}: \chi^{2}=1.46, \mathrm{df} 2, \mathrm{p}>0.4 ; \mathrm{B}: \chi^{2}=1.71, \mathrm{df}=\right.$ $2, \mathrm{p}>0.4 ; \mathrm{C}: \chi^{2}=0.08, \mathrm{df}=2, \mathrm{p}>0.95 ; \mathrm{D}: \chi^{2}=1.28$, $\mathrm{df}=2, \mathrm{p}>0.5$; Fig. 3 ) between collection methods

\section{DISCUSSION}

Efficient collection of urchins from barrens while still ensuring high survival and high GIs at the end of the roe enhancement period is essential if commercial-scale production is to be financially fea-

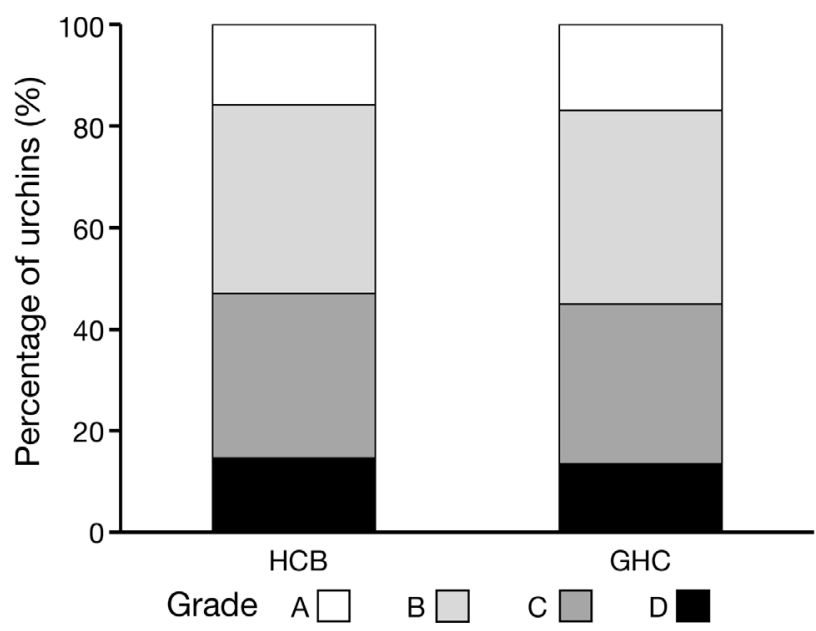

Fig. 3. Comparison of urchin roe grades between 2 different collection methods, i.e. hook and catch bag (HCB) and gentle hand and container (GHC). Grading method based on Pert et al. (2018) 
sible. Urchin collection by divers was 1.9 times faster with HCB than with the GHC method. Yet both methods had very low mortality, similar GIs and similar proportions of urchins in healthy and average condition after $12 \mathrm{wk}$ of roe enhancement.

\subsection{Collection rates}

Having an efficient collection method that is easy for divers and ensures minimal product loss during roe enhancement is important for keeping collection costs as low as possible. Base casual rates for inshore commercial divers start around AUD $\$ 32 \mathrm{~h}^{-1}$, plus allowances (www.fairwork.gov.au), but diver rates may be as high as AUD $\$ 80 \mathrm{~h}^{-1}$, depending on diver demand (B. Cleveland pers. comm.). At rates of between $\$ 32$ and $80 \mathrm{~h}^{-1}$, if a diver spends $6 \mathrm{~h}$ out of an $8 \mathrm{~h}$ working day in the water collecting urchins using the HCB method, they could collect in excess of 2000 urchins $\mathrm{d}^{-1}$. This equates to a collection cost of $\sim$ \$0.13-0.32 urchin $^{-1}$ before transportation to the roe enhancement facility.

\subsection{Mortality rates}

To reduce handling stress and ensure better survival, air exposure was minimised and urchins were held in seawater with a continuous flow of pure oxygen supplied via air stones during transport. Total mortality was $<2 \%$ after 12 wk for both collection methods for urchins held in ambient water temperatures that dropped from 14.4 to $12.3^{\circ} \mathrm{C}$ during the roe enhancement period. Less than $2 \%$ mortality is similar to that reported by Pert et al. (2018) for urchins collected and roe enhanced in ambient seawater at $14 \pm 0.5^{\circ} \mathrm{C}$. However, using the same collection method (handpicked and oxygenation during transport), Pert et al. (2018) found that urchins collected for roe enhancement at $18^{\circ} \mathrm{C}$ and held in ambient water that dropped from 18 to $15^{\circ} \mathrm{C}$ over the $12 \mathrm{wk}$ enhancement period suffered a total mortality of $5 \%$, whilst urchins held in $22^{\circ} \mathrm{C}$ suffered $20 \%$ total mortality. Although here we had very low mortality for both $\mathrm{HCB}$ and $\mathrm{GHC}$ when collecting at $15^{\circ} \mathrm{C}$, there is a possibility that higher total mortality may occur with both collection methods when urchins are collected or roe enhanced in waters at temperatures above $15^{\circ} \mathrm{C}$. Extended air exposure can also increase mortality rates regardless of the handling method (Dale et al. 2005), which could be a greater issue if urchins are collected on hot days. Here, we ensured one of the prerequisites for optimal collection of urchins for roe enhancement, i.e. minimal air exposure while on board the boat and during transit to the aquaculture facility.

\subsection{Urchin health and gonad condition}

There was no difference in external urchin health or gonad conditioning between the HCB and GHC collection methods, with the majority of urchins $(\sim 90 \%)$ being in healthy condition at the end of the enhancement period. Furthermore, the average GIs increased 6 -fold, from 2 to $\sim 13 \%$. In contrast to our results, rough handling during collection of the urchin Strongylocentrotus droebachiensis (Dale et al. 2005) may cause external damage and result in reduced GIs after roe enhancement, which suggests that rough handling may have species-specific effects on final GIs after roe enhancement.

\section{CONCLUSION}

Hooks were twice as efficient as hands for urchin collection and did not result in higher mortality or lower urchin condition or GIs after roe enhancement. Both methods used pure oxygen during the transport stage, which for a large-scale commercial venture might be an unnecessary added cost to collection. Aeration alone may be sufficient to ensure high survival during the transport stage. Collection of urchins when sea temperatures are $\leq 15^{\circ} \mathrm{C}$ will ensure high survival rates during the transport phase. As long as air exposure is minimised, how urchins are picked off a barren (by hand or by hook) or transferred from a barren (in a container or a catch bag) to holding tanks on the boat does not influence total mortality or the condition of urchins during roe enhancement.

Acknowledgements. This work was supported by Agrifutures project no. PRJ-010410 'Solving key industry bottlenecks for sea urchin roe enhancement' to T.D., S.E.S. and G.M.T. We thank Dean Chamberlain and Ben Cleveland for their assistance with urchin collection.

\section{LITERATURE CITED}

Andrew NL, Underwood AJ (1993) Density-dependent foraging in the sea urchin Centrostephanus rodgersii on shallow subtidal reefs in New South Wales, Australia. Mar Ecol Prog Ser 99:89-98

Böttger SA, Devin MG, Walker CW (2006) Suspension of annual gametogenesis in North American green sea 
urchins (Strongylocentrotus droebachiensis) experiencing invariant photoperiod-applications for land-based aquaculture. Aquaculture 261:1422-1431

Chapman ARO (1981) Stability of sea urchin dominated barren grounds following destructive grazing of kelp in St Margaret's Bay, eastern Canada. Mar Biol 62:307-311

Claisse JT, Williams JP, Ford T, Pondella DJ, Meux B, Protopapadakis L (2013) Kelp forest habitat restoration has the potential to increase sea urchin gonad biomass. Ecosphere 4:38

Dale T, Siikavuopio SI, Aas K (2005) Roe enhancement in sea urchin: effects of handling during harvest and transport on mortality and gonad growth in Strongylocentrotus droebachiensis. J Shellfish Res 24:1235-1239

Fletcher W (1987) Interactions among subtidal Australian sea urchins, gastropods, and algae: effects of experimental removals. Ecol Monogr 57:89-109

James PJ (2006) The effects of wave and feeding disturbance on roe enhancement of the sea urchin Evechinus chloroticus held in sea-cages. Aquaculture 252:361-371

James P, Evensen T, Samuelsen A (2017) Commercial scale sea urchin roe enhancement in Norway: enhancement, transport and market assessment. Nofima rapportserie Rep 7/2017. Nofima, Tromsø

Johnson CR, Swearer SE, Ling SD, Reeves S and others (2015) The reef ecosystem evaluation framework: managing for resilience in temperate environments. University of Tasmania, Hobart. http://ecite.utas.edu.au/112241

Kriegisch N, Reeves S, Johnson CR, Ling SD (2016) Phaseshift dynamics of sea urchin overgrazing on nutrified reefs. PLOS ONE 11:e0168333

Lawrence JM (ed) (2001) Edible sea urchins: biology and ecology. Dev Aquacult Fish Sci, Vol 32. Elsevier Amsterdam

Ling S (2008) Range expansion of a habitat-modifying species leads to loss of taxonomic diversity: a new and impoverished reef state. Oecologia 156:883-894

LLing S, Scheibling R, Rassweiler A, Johnson C and others (2015) Global regime shift dynamics of catastrophic sea urchin overgrazing. Philos Trans R Soc B 370:20130269

Midling KØ, Koren C, Humborstad OB, Sæther BS (2012) Swimbladder healing in Atlantic cod (Gadus morhua), after decompression and rupture in capture-based aquaculture. Mar Biol Res 8:373-379

Musgrove RJ (2005) Aquaculture and diet development subprogram: post harvest enhancement of sea urchin roe for the Japanese market. SARDI Aquatic Sciences, Adelaide

Olsen SH, Tobiassen T, Akse L, Evensen TH, Midling KØ (2013) Capture induced stress and live storage of Atlantic cod (Gadus morhua) caught by trawl: consequences for the flesh quality. Fish Res 147:446-453

Editorial responsibility: Alejandro Buschmann,

Puerto Montt, Chile
Pert CG, Swearer SE, Dworjanyn S, Kriegisch N, Turchini GM, Francis DS, Dempster T (2018) Barrens of gold: gonad conditioning of an overabundant sea urchin. Aquacult Environ Interact 10:345-361

Robinson SMC, Castell JD, Kennedy EJ (2002) Developing suitable colour in the gonads of cultured green sea urchins (Strongylocentrotus droebachiensis). Aquaculture 206:289-303

"Scheibling RE, Hennigar AW, Balch T (1999) Destructive grazing, epiphytism, and disease: the dynamics of sea urchin-kelp interactions in Nova Scotia. Can J Fish Aquat Sci 56:2300-2314

* Senaratna M, Evans LH, Southam L, Tsvetnenko E (2005) Effect of different feed formulations on feed efficiency, gonad yield and gonad quality in the purple sea urchin Heliocidaris erythrogramma. Aquacult Nutr 11: 199-207

Shears NT, Babcock RC (2002) Marine reserves demonstrate top-down control of community structure on temperate reefs. Oecologia 132:131-142

Shpigel M, McBride SC, Marciano S, Ron S, Ben-Amotz A (2005) Improving gonad colour and somatic index in the European sea urchin Paracentrotus lividus. Aquaculture 245:101-109

Steneck RS, Graham MH, Bourque BJ, Corbett D, Erlandson JM, Estes JA, Tegner MJ (2002) Kelp forest ecosystems: biodiversity, stability, resilience and future. Environ Conserv 29:436-459

Suckling CC, Symonds RC, Kelly MS, Young AJ (2011) The effect of artificial diets on gonad colour and biomass in the edible sea urchin Psammechinus miliaris. Aquaculture 318:335-342

* Tracey S, Mundy C, Baulch T, Marzloff M, Hartmann K, Ling S, Tisdell J (2014) Trial of an industry implemented, spatially discrete eradication/control program for Centrostephanus rodgersii in Tasmania. Fisheries Research and Development Corporation. www.frdc. com.au/Archived-Reports/FRDC\%20Projects/2011-087DLD.pdf

Tracey SR, Baulch T, Hartmann $\mathrm{K}$, Ling SD, Lucieer V, Marzloff MP, Mundy C (2015) Systematic culling controls a climate driven, habitat modifying invader. Biol Invasions 17:1885-1896

Verachia W, Niven B, Bremer PJ (2012) The effect of postharvest handling and processing on sea urchin (Evechinus chloroticus) gonad quality. Int J Food Sci Technol 47:2545-2553

Woods CM, James PJ, Moss GA, Wright J, Siikavuopio S (2008) A comparison of the effect of urchin size and diet on gonad yield and quality in the sea urchin Evechinus chloroticus Valenciennes. Aquacult Int 16:49-68

Submitted: August 24, 2018; Accepted: February 14, 2019

Proofs received from author(s): April 4, 2019 